\title{
Water Soluble Mixed Ligand Complexes Spectral, antioxidant, antimicrobial and DNA interaction studies
}

\author{
KARUNGANATHAN SAKTHIKUMAR ${ }^{1}$, MURUGESAN SANKARGANESH ${ }^{1}$, JEYARAJ DHAVEETHU RAJ A ${ }^{1 *}$, LIVIU MITU2* \\ ${ }^{1}$ Chemistry Research Centre, Mohamed Sathak Engineering College, Kilakarai, 623806, Tamilnadu, India \\ ${ }^{2}$ University of Pitesti, Department of Nature Sciences, 1 Targu din Vale, 110040, Pitesti, Romania
}

\begin{abstract}
A new series of water soluble mixed ligand complexes [ $\left.M^{\prime \prime}(L)(b p y) A c O\right] . n H_{2} \mathrm{O} M=C u_{1}(n=1)(1)$; $C o(2)$, $\mathrm{Mn} \mathrm{(3),} \mathrm{Ni} \mathrm{(4)} \mathrm{(} n=4)$ and $\mathrm{Zn}(5)(n=2)$ have been synthesized from 2-(2-Morpholinoethylimino) methyl)phenol Schiff base ligand $(\mathbf{H L})$ and 2,21-bipyridine in a 1:1:1 molar ratio. The resulting complexes were characterized by spectral techniques. The spectral data of these complexes suggest an octahedral geometry. In vitro antioxidant activity results of DPPH assay, hydroxyl radical, super oxide and nitric oxide for complexes (1-5) were compared with ligand $(\mathbf{H L})$ and in vitro antimicrobial activities of all compounds were examined against selected bacterial and fungal strains which indicate that the complexes exhibithigher antimicrobial activity than free ligand (HL). Gel electrophoresis results indicated that, complexes (1) and (2) have exhibited more DNA cleavage efficiency than others. The intrinsic binding constant $\left(K_{b}\right)$ values for the complexes (15) observed by electronic absorption technique were in the order of (1) > (4) > (5) > (2) > (3) and DNA binding affinity values for these complexes obtained by viscosity measurements were in the order of ethidium bromide $>(1)>(2)>(3)>(4)>(5)$.
\end{abstract}

Keywords: Schiff base, bipyridine, octahedral, DNA interactions

Schiff base complexes of transition metal have played a prominent role in the development of coordination chemistry. Over recent years a huge number of mixed ligand transition metal(II) complexes having N, 0 and S donor binding sites have been found to play a vital role in biological systems, clinical, medicinal, agricultural, industrial, analytical and therapeutic applications [1-3]. Heterocyclic bases like morpholine, pyrimidine derivative complexes have been extensively studied because of their potential antimicrobial and anticancer activities $[4,5]$ and they are exhibited unusual electronic properties, diverse chemical reactivity and peculiar structure which result in non-covalent interactions with DNA [6]. The ternary $\mathrm{Cu}(I I)$ complexes of 2,21-bipyridine that are strongly bound to DNA and cleave DNA oxidatively and exhibit cytotoxicity $[7,8]$ and also reported that the binding studies of mixed ligand $\mathrm{Cu}(\mathrm{II})$ complexes of diimines with DNA. When it interacts with DNA may induce the breakage of DNA, after cleavage of DNA double strands, the replication ability of the cancer gene is thereby destroyed. They exhibit more efficient anticancer activity than that of cisplatin [9].

Vitamins $C$ and $E$ are found in generous amounts in fruits and vegetables which are natural antioxidants belong to the group of polyphenolic compounds prevents the risk of several aging related diseases and human pathologies, including cancer and cardio cerebral-vascular diseases, diabetes mellitus, etc. The antioxidant compounds can act as reduction agents which reduces the effects of dangerous oxidants by binding together with these harmful molecules, decreasing their destructive power and antioxidants can also help to repair damage al ready sustained by cells [10] It is well known that the antioxidant activity is reasonably related to the electrochemical behavior where low oxidation potential meant high antioxidant power [11]. Keeping the above facts in mind, we are enticed to continue our research work on the synthesis of mixed ligand transition metal complexes (1-5) from morpholine substituted Schiff base incorporating 2,21-bipyridine, structural elucidation, antioxidant, antimicrobial and DNA interaction studies.

\section{Experimental part}

Materials and methods

All required materials and solvents were purchased from Sigma Aldrich Chemical Company and solvents were of analytical grade.

\section{Synthesis of mixed ligand complexes}

The preparation of 2-(2-morpholinoethylimino) methyl) phenol Schiff base ligand $(\mathbf{H L})$ has been reported in our previous research paper [12]. A solution of 2-(2Morpholinoethylimino)methyl) phenol Schiff base (HL) (Primaryligand) $(0.001 \mathrm{M})$ in methanol $(40 \mathrm{~mL})$ was added slowly to a solution of Metal(II) acetate $(0.001 \mathrm{M})$ $\mathrm{Cu}(\mathrm{OAc}), \mathrm{H}, \mathrm{O}, \mathrm{Zn}(\mathrm{OAc}), 2 \mathrm{H}_{2} \mathrm{O}, \mathrm{Mn}(\mathrm{OAc}), 4 \mathrm{H}_{2} \mathrm{O}, \mathrm{Co}(\mathrm{OAC})$. $4 \mathrm{H}_{2} \mathrm{O}$ and $\mathrm{Ni}(\mathrm{OAC})_{2} \cdot 4 \mathrm{H}_{2} \mathrm{O}$ in $30 \mathrm{~mL}$ of absolute methanol and the resulting mixture was stirred for $30 \mathrm{~min}$ and the hot mixture of solution slowly added into methanolic solution of 2,2'-bipyridine as secondary ligand (0.001 M). The obtaining mixture was refluxed for $3 \mathrm{~h}$. The solid product so formed was separated by filtration and purified by recrystallization using methanol and petroleum ether. Trace of water and solvents were recovered by keeping in vacuum desiccators over anhydrous $\mathrm{CaCl}_{\text {. }}$. The preparation of all complexes was followed by the similar method and the yield was found to be $71-82 \%$ (scheme 1) and (table $1)$.

\section{In vitro antioxidant assay}

The antioxidant activity of ligand $(\mathbf{H L})$ and complexes (1-5) were analysed by various free radicals such as 2,2diphenyl-1-(2,4,6-trinitrophenyl)hydrazyl, hydrogen peroxide, superoxide radical and nitric oxide [12-16].

\section{Pharmacological study - In vitro antimicrobial assay}

Antimicrobial activities of the ligand (HL) and complexes (1-5) were screened in vitro against the selected pathogenic bacterial strains and fungi species by the disc diffusion method [17].

email: jdrajapriya@gmail.com; Phone: +91 94876 82202; ktm7ro@yahoo.com; Phone: 0040/725160304 


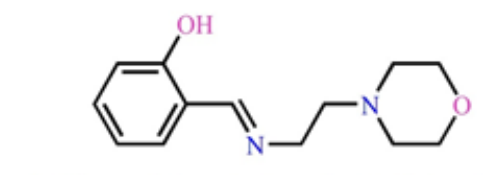

2-(-(2-morpholinoethylimino)methyl)phenol (LH)

[M"(L)(bpy)AcO]. $\mathrm{nH}_{2} \mathrm{O}$ Complex

$\mathrm{M}=\mathrm{Cu}(\mathrm{II})(\mathrm{n}=1) ; \mathrm{Co}(\mathrm{II}), \mathrm{Ni}(\mathrm{II}), \mathrm{Mn}(\mathrm{II})(\mathrm{n}=4) \& \mathrm{Zn}$ (II) $(\mathrm{n}=2)$
Scheme 1. Schematic representation of synthesis of ligand (HL) and complexes (1-5)
Table 1

ANALYTICAL AND PHYSICAL DATA OF SCHIFF BASE LIGAND (HL) AND ITS MIXED LIGAND COMPLEXES (1-5)

\begin{tabular}{|c|c|c|c|c|c|c|c|c|}
\hline \multirow{2}{*}{$\begin{array}{l}\text { Compounds } \\
\text { (EF \& FW) }\end{array}$} & \multirow{2}{*}{ Colour } & \multirow{2}{*}{$\begin{array}{c}\text { Yield( } \\
\%)\end{array}$} & \multirow{2}{*}{$\underset{{ }^{\circ} \mathrm{C}}{\mathrm{MP}}$} & \multicolumn{4}{|c|}{ Found (Calcd), \% } & \multirow[b]{2}{*}{$\wedge_{\mathrm{m}}$} \\
\hline & & & & $\mathrm{C}$ & $\mathrm{H}$ & $\mathrm{N}$ & $\mathrm{M}$ & \\
\hline $\begin{array}{c}\text { (HL) }\left(\mathrm{C}_{13} \mathrm{H}_{18} \mathrm{~N}_{2} \mathrm{O}_{2}\right) \\
(234.31)\end{array}$ & Yellow & 87.48 & - & $\begin{array}{c}66.90 \\
(66.64)\end{array}$ & $\begin{array}{c}07.60 \\
(07.74)\end{array}$ & $\begin{array}{c}11.39 \\
(11.95)\end{array}$ & -- & -- \\
\hline 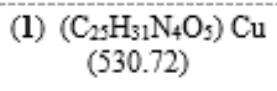 & Green & 82.00 & 105 & $\begin{array}{l}56.18 \\
(56.52)\end{array}$ & $\begin{array}{c}05.50 \\
(05.84)\end{array}$ & $\begin{array}{c}10.21 \\
(10.55)\end{array}$ & $\begin{array}{c}11.74 \\
(11.97)\end{array}$ & 40.24 \\
\hline 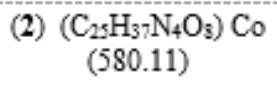 & $\begin{array}{c}\text { Dark } \\
\text { Brown }\end{array}$ & 73.66 & 112 & $\begin{array}{c}51.34 \\
(51.71)\end{array}$ & $\begin{array}{c}06.13 \\
(06.42)\end{array}$ & $\begin{array}{c}09.13 \\
(09.65)\end{array}$ & $\begin{array}{c}10.01 \\
(10.15)\end{array}$ & 35.92 \\
\hline 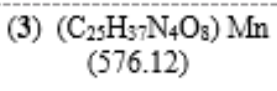 & Black & 75.34 & 220 & $\begin{array}{c}52.78 \\
(52.07)\end{array}$ & $\begin{array}{c}06.10 \\
(06.47)\end{array}$ & $\begin{array}{c}09.15 \\
(09.72)\end{array}$ & $\begin{array}{c}09.05 \\
(09.53)\end{array}$ & 30.86 \\
\hline 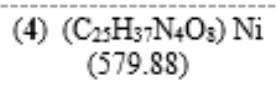 & $\begin{array}{l}\text { Dark } \\
\text { green }\end{array}$ & 75.40 & 85 & $\begin{array}{c}51.07 \\
(51.73)\end{array}$ & $\begin{array}{c}06.18 \\
(06.43)\end{array}$ & $\begin{array}{c}10.03 \\
(09.65)\end{array}$ & $\begin{array}{c}10.04 \\
(10.12)\end{array}$ & 38.21 \\
\hline 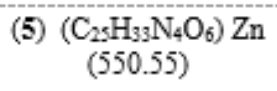 & $\begin{array}{c}\text { Pale } \\
\text { brown }\end{array}$ & 78.55 & 75 & $\begin{array}{l}54.03 \\
(54.49)\end{array}$ & $\begin{array}{c}05.88 \\
(06.04)\end{array}$ & $\begin{array}{c}09.85 \\
(10.17)\end{array}$ & $\begin{array}{c}11.66 \\
(11.87)\end{array}$ & 32.40 \\
\hline
\end{tabular}

$\mathrm{ML}$ (bpy), (bpy $=2,2^{\prime}$-bipyridine), $\mathrm{M}=\mathrm{Cu}, \mathrm{Co}, \mathrm{Mn}, \mathrm{Ni}, \mathrm{Zn}$,

$\mathrm{EM}=$ Empirical Formula, $\mathrm{FW}=$ Formula Weight,$\wedge_{\mathrm{m}}=$ Molar conductance $\left(\mathrm{ohm}^{-1} \mathrm{~cm}^{2} \mathrm{~mol}^{-1}\right)$

DNA interaction studies - DNA cleavage study by gel electrophoresis

DNA cleavage activities of ligand ( $\mathbf{H L}$ ) and complexes (1-5) with CT-DNA were monitored by agarose gel electrophoresis method [18, 19].

\section{DNA binding study by electronic absorption titration}

DNA binding studies of ligand $(\mathbf{H L})$ and complexes (15) with CT-DNA were assessed by electronic absorption spectral titrations and viscosity methods [12, 20, 21].

\section{Results and discussions}

Synthesis and characterization

The synthesized Schiff base ligand (HL) and its mixed ligand complexes (1-5) were found to be intensely coloured and they were slightly hygroscopic nature at room temperature. The synthesized mixed ligand complexes were soluble in water, methanol, ethanol, $\mathrm{CHCl}_{\text {, and DMSO. }}$ The analytical data and physical properties of the ligand (HL) and complexes

(1-5) are listed in the table 1 . The low value of conductivity shows that they are non electrolytic nature due to lack of dissociation.

\section{Electro spray ionization Mass spectra}

ESI-MS mass spectrometry is used to confirm the stoichiometry composition of compounds. The mass spectrum of ligand $(\mathbf{H L})$ shows the molecular ion peak at $\mathrm{m} / \mathrm{z} 235$ corresponding to $\mathrm{C}_{13} \mathrm{H}_{18} \mathrm{~N}_{2} \mathrm{O}_{2}$ and the [Cu"(L)(bpy)AcO]. $\mathrm{H}_{2} \mathrm{O}$ complex (1) molécular ion peak at $\mathrm{m} / \mathrm{z} 531.2$ corresponding to $\left[\left(\mathrm{C}_{25} \mathrm{H}_{3} \mathrm{~N}_{4} \mathrm{O}_{5}\right) \mathrm{Cu}\right]$ which confirms the formation of [ $\left.\mathrm{MLL}^{2}\right]$ stoichiometry (Scheme 1 ). The molecular ion peaks of other complexes were observed at $\mathrm{m} / \mathrm{z}$ with relative abundance $581.3(2), 577.2$ (3), 580.9 (4) and 551.1 (5) and they are in good agreement with the formula weight.

\section{${ }^{1} \mathrm{H}$ Nuclear Magnetic Resonance spectra}

The ${ }^{1} \mathrm{H}$ NMR spectra of the Schiff base ligand $(\mathbf{H L})$ and complex (5) show the following signals (fig. 1); $\delta$ values of Schiff base ligand: aromatic protons $(\mathrm{m}, 4 \mathrm{H})$ at $6.84-$ $7.32 \mathrm{ppm}$; azomethine proton $(-\mathrm{HC}=\mathrm{N}-)(\mathrm{s}, 1 \mathrm{H})$ at 8.35 ppm; morpholino- $\mathrm{OCH}_{2}$ protons $(\mathrm{t}, 4 \mathrm{H})$ at $3.72 \mathrm{ppm}$; morpholino- $\mathrm{N}_{-} \mathrm{CH}_{2}(\mathrm{t}, 4 \mathrm{H})$ at $2.44 \mathrm{ppm}$; phenolic-OH proton $(\mathrm{s}, 1 \mathrm{H})$ at $13.52 \mathrm{ppm}$ [22]. Complex (5): aromatic protons $(\mathrm{m}, 10 \mathrm{H})$ at $6.88-7.51 \mathrm{ppm}$; azomethine proton $(-\mathrm{HC}=\mathrm{N}-)$ $(\mathrm{s}, 1 \mathrm{H})$ at $8.53 \mathrm{ppm} ; \mathrm{bpy}-\mathrm{CH}=\mathrm{N}$ proton $(\mathrm{s}, 2 \mathrm{H})$ at $8.88 \mathrm{ppm}$; morpholino- $\mathrm{OCH}_{2}(\mathrm{t}, 4 \mathrm{H})$ at $3.72 \mathrm{ppm}$; morpholino- $\mathrm{N}-\mathrm{CH}_{2}$ $(\mathrm{t}, 4 \mathrm{H})$ at $2.78 \mathrm{ppm}$; acetate protons $\left(\mathrm{CH}_{3} \mathrm{COO}-\right)(\mathrm{s}, 3 \mathrm{H})$ at $2.038 \mathrm{ppm}$. The above ${ }^{1} \mathrm{H}$ NMR spectra data assigned that the azomethine proton and morpholino- $\mathrm{N}-\mathrm{CH}_{2}$ proton signals in the spectrum of the complex (5) are shifted down field compared to the free ligand suggesting deshielding 


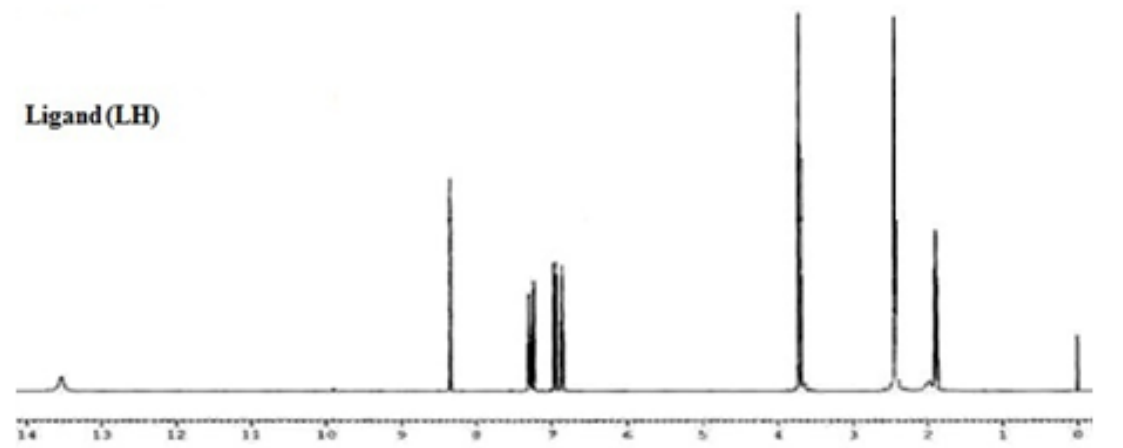

Complex (5)
Fig. 1. ${ }^{1} \mathrm{H}-\mathrm{NMR}$ spectra of Schiff base ligand (HL) and complex (5)

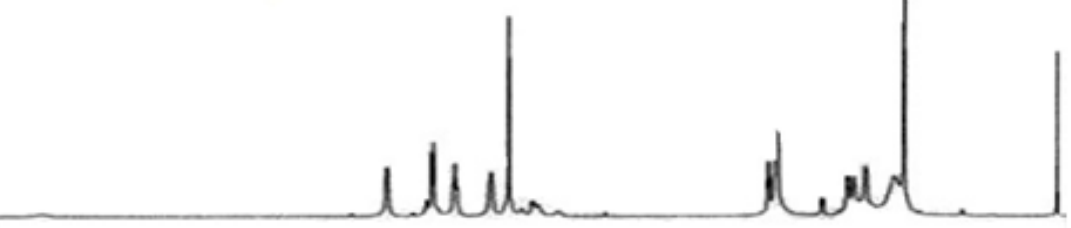

due to nitrogen atom is taking part in complexation [ 23 , 24]. The absence of singlet peak at the rage of $13 \mathrm{ppm}$ was noted that the complex (5) indicates the loss of the$\mathrm{OH}$ proton due to complexation [25] and there is no appreciable change in other signals in the complex (5).

\section{FTIR spectra}

The FTIR spectra of the complexes (1-5) were compared with the free ligand $(\mathbf{H L})$ for the frequency changes during the complexation (table 2). In the FTIR spectrum of Schiff base ligand $(\mathbf{H L})$ a strong sharp band was observed at $1635 \mathrm{~cm}^{-1}$ which is assigned to the azomethine group $(-\mathrm{HC}=\mathrm{N}-)$ and shifted to lower frequencies in the spectra of the complexes (1-5) indicating the involvement of imino nitrogen in coordination to the central metal ion [26] and aliphatic morpholino -C-N-C bands at $1342 \mathrm{~cm}^{-1}$ found in the ligand $(\mathbf{H L})$ is shifted lower frequencies in the spectra of the complexes (1-5) indicating the involvement of $\mathrm{C}-\mathrm{N}-\mathrm{C}$ nitrogen in coordination to the metal ion. The peak of ligand $(\mathbf{H L})$ belonging to $-\mathrm{OH}$ group is identified at $3676 \mathrm{~cm}^{-1}$, the peak is disappeared in spectra of the complexes (1-5) which indicates the deprotonation of -OH group upon complexation [27] and also the peak at $1278 \mathrm{~cm}^{-1}$ for the phenolic C-O group in the ligand ( $\mathbf{H L}$ ) is shifted to higher frequencies in the spectra of the complexes (1-5) indicating confirming deprotonation of the phenolic -OH on chelation [28]. In the spectra of metal complexes (1-5) a broad diffuse band was identified in the range $3500-3350 \mathrm{~cm}^{-1}$ and another weak band in-plane bending (rocking) in the range $858-828 \mathrm{~cm}^{-1}$. It suggests that the presence of water molecules in the complexes (1-5) [29,30]. In the complexes (1-5), two bands appeared in the region 1668-1664 $\mathrm{cm}^{-1}\left(\gamma_{\text {asymmetry }}\right)$ and $1404-1398$ $\mathrm{cm}^{-1}\left(\gamma_{\text {symmetry }}\right)$ which attribute the carboxylate part in the acetate group and also suggest that they are responsible for the consisting of unidentate coordination site with the metal ion due to the value of differences between asymmetry and symmetry was greater than $200 \mathrm{~cm}^{-1}$ $\left(\Delta \gamma \geq 200 \mathrm{~cm}^{-1}\right)$ [31]. The far IR spectra of the complexes (1-5) show medium bands in the region $471-462 \mathrm{~cm}^{-1}$ and $516-498 \mathrm{~cm}^{-1}$ corresponding to $v \mathrm{M}-\mathrm{N}$ and $v \mathrm{M}-\mathrm{O}$ vibrations respectively [32] and other absorption bands were no appreciable change in the ligand $(\mathbf{H L})$ and metal complexes (1-5).

\section{Electronic spectra and Magnetic susceptibility}

The electronic spectra of the free ligand $(\mathbf{H L})$ displayed two bands at $258 \mathrm{~nm}\left(38760 \mathrm{~cm}^{-1}\right)$ and $319 \mathrm{~nm}(31348$ $\mathrm{cm}^{-1}$ ) were intraligand charge transfer assigned to $\pi \rightarrow \pi^{*}$ and $n \rightarrow \pi^{*}$ transitions for phenyl ring and the azomethine chromophore $(-\mathrm{CH}=\mathrm{N}-)$ respectively [33]. The bands for the metal complexes (1-2) and (4) are shifted to a longer

\begin{tabular}{|c|c|c|c|c|c|c|c|c|c|}
\hline Compounds & $\mathrm{HC}=\mathrm{N}$ & $\begin{array}{c}\text { bpy } \\
v(\mathrm{C}=\mathrm{N})\end{array}$ & $\begin{array}{l}\mathrm{Ph}- \\
\mathrm{C}-\mathrm{O}\end{array}$ & $\begin{array}{c}\text { Aliphatic } \\
\text { C-N-C }\end{array}$ & $\begin{array}{c}\text { Acetate } \\
\text { (s) } \\
\text { (as) }\end{array}$ & $\mathrm{Ph}-\mathrm{OH}$ & $\left(\mathrm{H}_{2} \mathrm{O}\right)$ & $\stackrel{v}{\mathrm{M}-\mathrm{N}}$ & $\stackrel{v}{\mathrm{M}-\mathrm{O}}$ \\
\hline Ligand (LH) & 1635 & -- & 1278 & 1342 & - & 3676 & - & - & - \\
\hline Complex (1) & 1596 & 1571 & 1310 & 1325 & $\begin{array}{l}1398 \\
1664\end{array}$ & - & 848 (b) & 464 & 508 \\
\hline Complex (2) & 1600 & 1573 & 1311 & 1320 & $\begin{array}{l}1402 \\
1664\end{array}$ & - & $846(b)$ & 466 & 498 \\
\hline Complex (3) & 1621 & 1575 & 1302 & 1336 & $\begin{array}{l}1402 \\
1668\end{array}$ & - & $828(b)$ & 470 & 508 \\
\hline Complex (4) & 1596 & 1571 & 1309 & 1334 & $\begin{array}{l}1402 \\
1668\end{array}$ & - & $836(b)$ & 462 & 516 \\
\hline Complex (5) & 1627 & 1573 & 1308 & 1335 & $\begin{array}{l}1402 \\
1664\end{array}$ & - & $858(b)$ & 471 & 510 \\
\hline
\end{tabular}

Table 2

FTIR SPECTRAL DATA OF SCHIFF BASE $\operatorname{LIGAND}(\mathrm{HL})$ AND COMPLEXES

(1-5) $\left(\mathrm{cm}^{-1}\right)$

bpy $=2,2$ '-bipyridine, Ph-C-O = Phenolic C-O group, Aliphatic C-N-C = Morpholino C-N-C,

$\mathrm{s}=$ symmetry, as = asymmetry, $\mathrm{Ph}-\mathrm{OH}=$ Phenolic $\mathrm{OH}, \mathrm{b}=\mathrm{In}$ plane bending (rocking) 
wavelength which may be attributed to the donation of lone pair electron in a $\mathrm{sp}^{2}$-hybridized orbital of the imino nitrogen atom of the ligand to the metal $(\mathrm{N} \rightarrow \mathrm{M})$. Complex (1) exhibited only one low intensity broad band d-d transition at $647 \mathrm{~nm}\left(15455 \mathrm{~cm}^{-1}\right)$ due to dynamic JahnTeller distortion [34, 35]. It is assigned to the ${ }^{2} \mathrm{E}_{\rightarrow}{ }^{2} \mathrm{~T}_{2}$ transition and its magnetic moment $\left(v_{\text {eff }}\right)$ value is $1.81 \mathrm{BM}$ which is slightly higher than the spin only value (1.73 BM) for one unpaired electron which suggests possibility of a distorted octahedral geometry [36, 37]. The electronic spectrum of complex (2) showed three bands at 886 $\mathrm{nm}\left(11286 \mathrm{~cm}^{-1}\right), 525 \mathrm{~nm}\left(19047 \mathrm{~cm}^{-1}\right)$ and $404 \mathrm{~nm}(24752$ $\left.\mathrm{cm}^{-1}\right)$ corresponding to the transitions ${ }^{4} \mathrm{~T}_{1}(\mathrm{~F}) \rightarrow{ }^{4} \mathrm{~T}(\mathrm{~F})$, ${ }^{4} T_{1 g}(F) \rightarrow{ }^{4} A_{2}(F)$ and ${ }^{4} T_{1 g}(F) \rightarrow{ }^{4} T_{1 g}(P)$. Phe magnetic moment of the complex ${ }^{19}(\mathbf{2})$ was observed at 4.82 BM which was within the range 4.7-5.2 BM for octahedral geometry [38, 39]. The electronic spectrum of complex (4) showed three bands at $926 \mathrm{~nm}\left(10799 \mathrm{~cm}^{-1}\right), 553 \mathrm{~nm}$ $\left(18083 \mathrm{~cm}^{-1}\right)$ and $346 \mathrm{~nm}\left(28901 \mathrm{~cm}^{-1}\right)$ corresponding to the transitions ${ }^{3} \mathrm{~A}_{2 g}(\mathrm{~F}) \rightarrow{ }^{3} \mathrm{~T}_{20}(\mathrm{~F}),{ }^{3} \mathrm{~A}_{2}(\mathrm{~F}) \rightarrow{ }^{3} \mathrm{~T}_{10}(\mathrm{~F})$ and ${ }^{3} \mathrm{~A}_{2}$ $(F) \rightarrow{ }^{3} T_{1 q}(P)$. The magnetic moment of the complex (49) was observed at 3.13 BM which was within the range 2.53.5 BM for octahedral Ni(II) complexes [40]. Complexes (3) and (5) have no absorption in the visible domain which is in agreement with the electronic structure of the central metallic ion with $\mathrm{d}^{5}$ and $\mathrm{d}^{10}$ electronic configurations respectively. The crystal field theory does not predict the $d-d$ transitions of these complexes (3) and (5) due to absence of absorption bands in the visible region. The observed all spectral data results and magnetic moment values suggest an octahedral environment around the metal(II) ion.

\section{EPR spectra}

The X-band EPR spectra of the complex (1) in powder state was recorded at room temperature and liquid nitrogen temperature under $9.10 \mathrm{GHz}$ Microwave field modulation using tetracyanoethylene $\left(g_{e}=2.00277\right)$. The complex (1) exhibited one intense absorption band at 300 $\mathrm{K}$ in the high field region was isotropic due to the tumbling motion of the molecules and another one exhibited at frozen state $(77 \mathrm{~K})$ was anisotropic pattern with wellresolved hyperfine lines (fig. 2 and table 3 ).

The results are summarized in table 3. The spin Hamiltonian parameters have been calculated by Kivelson's method [12]. The observed g-values are in the order $g_{1}(2.1068)>g_{1}(2.01827)>g_{e}(2.00277)$ indicating that the unpaired electron lies predominantly in the $d_{x 2-x}$ orbital of Cu(II) [41] and the observed $g_{\| 1}$ values for complex (1) was less than 2.3 in agreement with the covalent environment character of the M-L bond [42]. The covalent nature of the $M-L$ bond in the complex (1) was further supported by the $g_{\text {off }}$ value which observed value was 1.3750 and less than 2.00277 [43]. The observed hyperfine

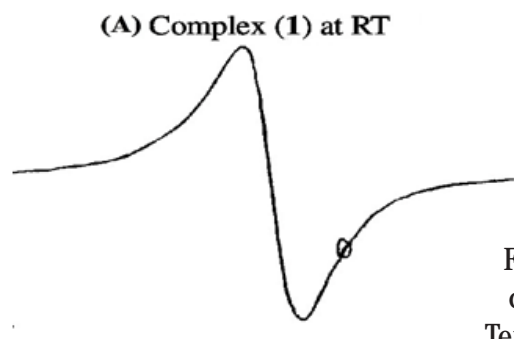

(B) Complex (1) at LNT

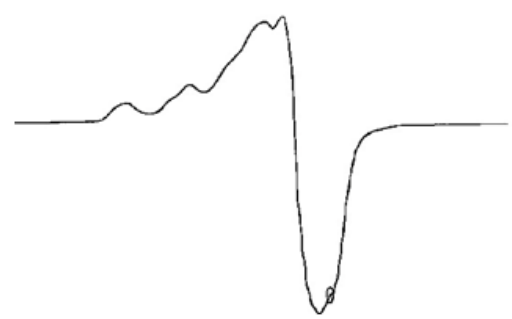

Fig. 2. The EPR spectra of complex (1) at (A) Room Temperature (300 K) and (B) Liquid Nitrogen Temperature (77 K)

constant parameters for the complex (1) were in the order $A_{1}=130 \mathrm{G}>A_{\text {av }}(103.33 G)>A=90 \mathrm{G}$ [12]. In the complex (1) the observed interaction coupling constant $(G)$ value $(6.6820)$ was larger than 4 suggesting that there is no interaction between Cu-Cu centers in the solid state complex and the absence of half field signal at $1600 \mathrm{G}$ corresponding to the $\Delta \mathrm{Ms}= \pm 2$ transition rules out a $\mathrm{Cu}$ $\mathrm{Cu}$ interaction [44]. The values of molecular orbital coefficient parameters $\left(\alpha^{2}, \beta^{2}, \gamma^{2}\right)$ were calculated by Kivelson and Neimann formulae in the previous published report [12]. The observed in-plane $\pi$-bonding parameter $\left(\alpha^{2}\right)$ value was 0.5 which indicates that the complex (1) has covalent character. The observed in-plane $\pi$-bonding $\left(\beta^{2}\right)$ and out-plane $\pi$-bonding $\left(\gamma^{2}\right)$ values were less than 1.0 which also indicate that the $\pi$-bonding is completely covalent character. The observed orbital reduction factor $\mathrm{K}_{\text {}}$ value was larger than $\mathrm{K}_{1}$, value for the complex (1) which indicates the presence of out-plane $\pi$-bonding in metal-ligand $\pi$-bonding [45]. The observed Co-factor $\left(\mathrm{f}_{\mathrm{f}}\right)$ value of degree of geometrical distortion for the complex (1) was $175.56 \mathrm{~cm}^{-1}$ which indicates an octahedral geometry around the $\mathrm{Cu}(\mathrm{II})$ ion. Spectral data and magnetic measurements of the complex (1) have been proposed as a distorted octahedral geometry (scheme 1).

\section{Cyclic voltammetry}

The electrochemical techniques are the most effective and versatile methods available for the mechanistic study of redox systems of the complexes. The cyclic voltammogram for complexes (1-5) reveals that one electron reduction peak ( $\left.E_{p c}\right)$ corresponding to $M(I I)$ to $M(I)$ and oxidation peak $\left(E_{p a}\right)$ corresponding to $M(I)$ to $M(I I)$. The observed values of peak-to-peak separation $\left(\Delta \mathrm{E}_{\mathrm{p}}\right)$ for complexes (1-5) was in the range of $255-862 \mathrm{mV}$ which is

\begin{tabular}{|c|c|c|c|c|c|c|c|}
\hline \multirow[t]{2}{*}{ Complex } & \multicolumn{3}{|c|}{ gtensor } & \multicolumn{3}{|c|}{$\begin{array}{l}\text { Hyperfine constant } \\
\times 10^{4} \mathrm{~cm}^{-1}\end{array}$} & \\
\hline & $\mathrm{gl}_{\mathrm{I}}$ & $g_{\perp}$ & $g_{w}$ & $A_{1}$ & $A_{\perp}$ & $A_{a v}$ & $\mathrm{G}$ \\
\hline \multirow{4}{*}{ Complex (1) } & 2.11 & 2.02 & 2.05 & 130 & 90 & 103.33 & 6.682 \\
\hline & \multicolumn{5}{|c|}{ Bonding parameters } & & \\
\hline & $\alpha^{2}$ & $\beta^{2}$ & $\gamma^{2}$ & $\mathrm{~K}_{\|}$ & $\mathrm{K}_{\perp}$ & $\mathrm{fll}_{\mathrm{l}}, \mathrm{cm}^{-1}$ & $\mu_{\text {eff, }}, \mathrm{BM}$ \\
\hline & 0.512 & 0.480 & 0.280 & 0.242 & 0.160 & 175.56 & 1.77 \\
\hline \multicolumn{8}{|c|}{$\begin{array}{l}\mathrm{g}_{\mathrm{s}}=2.00277, \text { Microwave frequency }\left(\gamma^{7}\right)=9.114 \mathrm{X} 10^{9} \mathrm{cycle} / \mathrm{sec}, \\
\text { Resonance magnetic field }(\mathrm{H})=3250 \text { gaus, } \mathrm{H}_{\diamond}=3240, \mathrm{H}_{\|}=3080, \\
\mathrm{H}_{1}=3215 \mathrm{G},\left(1 \mathrm{G}=10^{-4} \mathrm{~cm}^{-1}\right) \\
\mathrm{E}_{\mathrm{d}-\mathrm{d}}=15,455.95 \mathrm{~cm}^{-1} \text {, one-electron spin orbit coupling constant of } \\
\text { free Cu(II) ion } \\
\lambda_{0}=-828 \mathrm{~cm}^{-1}, \mu_{\mathrm{sff}}=1.81 \mathrm{BM}(\exp ), \text { Free ion dipolar term }(\mathrm{P})=0.036 \mathrm{~cm}^{-1}, \mathrm{f}\|=\mathrm{g}\| / \mathrm{A} \|, \mu_{\mathrm{off}}=\mathrm{g}_{\mathrm{sv}} \\
{[\mathrm{S}(\mathrm{S}+1)]^{1 / 2}}\end{array}$} \\
\hline
\end{tabular}

Table 3

THE EPR SPECTRAL DATA FOR POLYCRYSTALLINE SAMPLE OF THE COMPLEX (1) AT 77K 


\begin{tabular}{|c|c|c|c|c|c|c|c|c|c|}
\hline Complexes & Couple & $\begin{array}{l}E_{p a} \\
(V)\end{array}$ & $\begin{array}{l}E_{p c} \\
(V)\end{array}$ & $\begin{array}{c}\Delta \mathrm{E}_{\mathrm{p}} \\
(\mathrm{mV})\end{array}$ & $\begin{array}{l}E^{\circ} \\
(V)\end{array}$ & $\frac{i_{p \mathrm{p}}}{10^{-6} \mu \mathrm{A}}$ & $\begin{array}{c}i_{p a} \\
10^{-6} \mu \mathrm{A}\end{array}$ & $\begin{array}{l}i_{p v} / i_{p c}, \\
(\mu \mathrm{A})\end{array}$ & \multirow{6}{*}{$\begin{array}{c}\text { Table } 4 \\
\text { ELECTROCHEMICAL DATA OF } \\
\text { MIXED LIGAND } \\
\text { COMPLEXES (1-5) IN METHANOL } \\
\text { MEDIUM }\end{array}$} \\
\hline (1) & $\begin{array}{l}\mathrm{Cu}(\mathrm{II}) \\
\mathrm{Cu}(\mathrm{I})\end{array}$ & -0.5424 & -0.9827 & 440 & -0.7625 & 1.7509 & -3.7512 & -0.4667 & \\
\hline (2) & $\begin{array}{l}\mathrm{Co}(\mathrm{II}) \mathrm{r} \\
\mathrm{Co}(\mathrm{I})\end{array}$ & -0.2520 & -1.1145 & 862 & -0.6832 & 2.3174 & -3.6223 & -0.6397 & \\
\hline (3) & $\begin{array}{l}\operatorname{Mn}(\mathrm{II}) \\
\operatorname{Mn}(\mathrm{I})\end{array}$ & 0.0983 & -0.3213 & 419 & -0.2230 & 1.4185 & -2.2920 & -0.6189 & \\
\hline (4) & $\begin{array}{l}\mathrm{Ni}(\mathrm{II}) \\
\mathrm{Ni}(\mathrm{I})\end{array}$ & -0.8646 & -1.1212 & 256 & -1.0029 & -1.6443 & -1.9493 & 0.8435 & \\
\hline (5) & $\begin{array}{c}\mathrm{Zn}(\mathrm{II}) 7^{-} \\
\mathrm{Zn}(\mathrm{I})\end{array}$ & -0.6024 & -0.8578 & 255 & -0.7301 & -1.0567 & -3.1011 & 0.3400 & \\
\hline
\end{tabular}

larger than the Nernstian value $\left[\left(\mathrm{E}_{\mathrm{p}}-\mathrm{E}_{\mathrm{pc}}\right)\right.$ (or) $\Delta \mathrm{E}_{\mathrm{p}}=$ $2.303 R T / n F=59 / n \mathrm{mV}$ ] for the $\mathrm{M}(\mathrm{II}) / \mathrm{M}(\mathrm{I}) \mathrm{C}^{\mathrm{C}}$ redox couple revealing that this process is the best quasi-reversible and if the peak current ratio is greater or less than unity $\left(i_{0} / i_{\text {pr }}>\right.$ or $<1$ ) which represents quasi-reversible one electron transfer process [46]. The observed values of peak current ratio of complexes (1-5) were less than unity. In quasireversible the peak current $\left(\mathrm{i}_{\mathrm{p}}\right)$ is proportional to the root of the scan rate $(\sqrt{U})$ and separation in peak potential $\left(\Delta E_{p}\right)$. The observed values of formal electrode potential $\left(E^{0}\right)$ were in the ranges -0.2230 to $-1.0029 \mathrm{~V}$ which indicate that each couple corresponds to one electron transfer process (table 4).

\section{(a) DPPH radical scavenging assay}

Antioxidants are chemical substances that donate an electron to the free radical and convert into a harmless molecule. They may decrease the energy of the free radical or suppress radical formation or break chain propagation or repair damage and reconstitute membranes. DPPH free radical method is an antioxidant assay based on electrontransfer that produces a violet solution in methanol [47, 48]. DPPH free radical is a stable at room temperature which can accepts hydrogen or electron from donors and gets reduced by a color change from purple to yellow. When the concentration of complexes increases the antioxidant potential also increases. It was observed that the complex (1) has exhibited better antioxidant potential than others (fig. 3). The DPPH radical scavenging assay provides a simple and rapid approach to evaluate antioxidants by electronic spectrophotometer and it can be useful to assess various products at a time.

\section{(b) Hydroxyl radical scavenging assay}

In biological systems, uncontrolled accumulations of hydrogen peroxide leads to the formation of oxygen free radicals which cause immense damage to cells membrane. Hydroxyl radical scavenging activity is indicted as the percentage of inhibition of the complexes (1-5) was found to be comparable to that of the ligand at all the concentration used in this study. The $50 \%$ inhibition of all compounds was observed from 14 to $16.0 \times 10^{-5} \mathrm{M}$ concentration [49]. The complex (1), complex (2) and complex (3) showed significant antioxidant activity compared to others (fig. 3).

\section{(c) Superoxide scavenging assay}

It is well known for the antioxidant properties and it is clear understand that the antioxidants have the ability to prevent oxidative damage induced by reactive oxygen species as it can interfere with the oxidation process by inhibiting the initiation or propagation of oxidizing chain reactions. In this study the antioxidant potential of ligand (HL) and complexes (1-5) was further assessed by their ability to quench superoxide ions. It was observed that both ligand $(\mathbf{H L})$ and complexes (1-5) showed an increasing trend in their superoxide radical quenching ability with increasing concentrations (fig. 3). In fact at 20 $\times 10^{-5} \mathrm{M}$ concentration they exhibited above $50 \%$ activity [50].
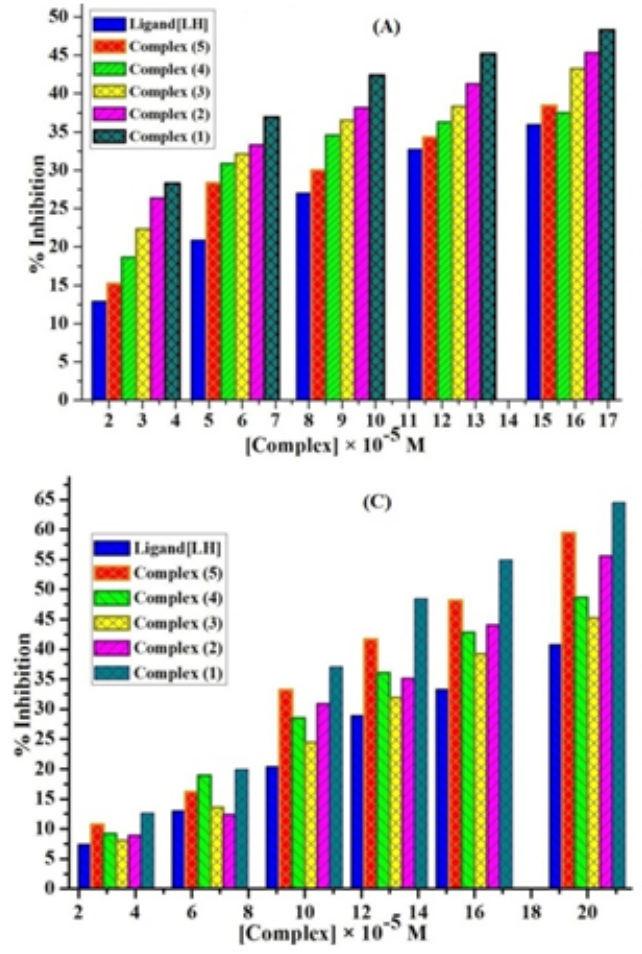

REV.CHIM.(Bucharest) 69 No. $11 \bullet 2018$
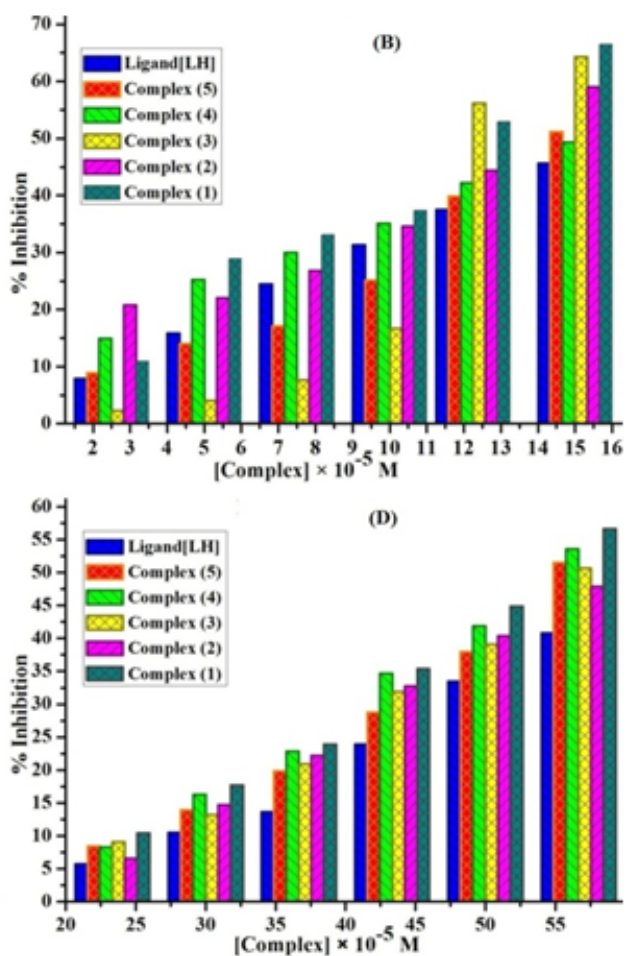

http://www.revistadechimie.ro
Fig. 3. (A) DPPH assay, (B) Hydroxyl radical scavenging, $(C)$ Super oxide scavenging and (D) Nitric oxide scavenging activity of ligand $(\mathbf{H L})$ and complexes (1-5) 


\section{(d) Nitric oxide scavenging assay}

Free radical scavenging potential of ligand $(\mathbf{H L})$ and complexes (1-5) was further confirmed by nitric oxide scavenging assay [51]. The nitric oxide radical inhibition was increased with increasing concentration of all compounds and they are exhibited moderate nitric oxide radical scavenging effect. The observed maximum nitric oxide radical inhibition of all compounds was found at concentration $55 \times 10^{-5} \mathrm{M}$. The all observed antioxidants results of ligand (HL) and complexes (1-5) are shown in (fig. 3).

\section{Antimicrobial assay}

It was observed the zones inhibition value $(\mathrm{mm})$ that complexes (1-5) exhibit good antimicrobial activity than the free ligand (HL) [52]. The observed higher activity of the metal complexes could be explained on the basis of Overtone's concept and Tweedy's chelation theory [53]. A possible explanation of higher antimicrobial activity for the complexes was clear attributed that the polarity of the metal ion in a chelated complex is reduced to a greater extent due to the overlap of the ligand orbital and partial sharing of the positive charge of the metal ion. It increases the delocalization of $\pi$ - and d-electrons over the whole chelated ring and enhances the lipophilicity of the metal complexes. The increased lipophilicity of complexes enhances the cell permeability into lipid membranes which leads to breakdown of the barrier of the cell and thus retards the normal cell processes [54]. The observed values of complexes (1), (2), (5) were significant antimicrobial activity than others and less than the standard drugs (Amikacin and Ketokonazole) [55] (table 5).
DNA interaction studies

(a) DNA nuclease activity by gel electrophoresis

The DNA cleavage efficiency of the complexes (1-5) was compared with DNA control (fig. 4). Lane: 1 for the control (DNA $+\mathrm{H}_{2} \mathrm{O}_{2}$ ) does not exhibit significant cleavage even on longer exposure time [56] and lane: 2 for the ligand (HL) alone was inactive in the presence and absence of external agents. Lane: 3 complex (1) and Lane: 4 complex (2), were cleaved DNA more efficiently in the presence of hydrogen peroxide than others. This may be attributed to the formation of hydroxyl free radicals $(\mathrm{OH} \cdot)$ which can be produced by metal ions reacting with $\mathrm{H}_{2} \mathrm{O}_{2}$ to produce the diffusible hydroxyl radical or molecular oxygen, which may damage DNA through Fenton type chemistry [57]. This hydroxyl radical participates in the oxidation of the deoxyribose moiety, followed by hydrolytic cleavage of sugar-phosphate backbone [58] and also the smear in the gel diagram indicates the presence of radical cleavage.

\section{(b) Evaluation of DNA binding constants by Electronic} absorption titration

Intrinsic binding constant $\left(\mathrm{K}_{\mathrm{b}}\right)$ and Gibbs free energy change $\left(\Delta G_{b}{ }^{\#}\right)$ values for complexes (1-5) have been evaluated by electronic absorption titration (fig. 5 ). The complexes (1-5) exhibittwo intense absorption bands. One intense band appeared in the region of 292-367 nm which assigned to $\pi-\pi^{*}$ intraligand charge transfer transitions and other one intense band in the region of $270 \mathrm{~nm}$ which attributed to ligand to center transfer [59]. The binding of the complexes to DNA helixes were characterized by monitoring the changes in the absorbance of $\pi-\pi^{*}$ bands and shift in wavelength on each addition of DNA solution

\begin{tabular}{|c|c|c|c|c|c|c|c|c|}
\hline \multirow[b]{2}{*}{ Compounds } & \multicolumn{5}{|c|}{ Antibacterial activity } & \multicolumn{3}{|c|}{ Antifungal activity } \\
\hline & $\begin{array}{c}(-) \\
\text { E. } \\
\text { coli }\end{array}$ & $\begin{array}{c}(-) \\
\text { S. } \\
\text { typhi }\end{array}$ & $\begin{array}{c}(-) \\
\mathrm{C} . \\
\text { bacterim }\end{array}$ & $\begin{array}{c}(+) \\
\text { S. } \\
\text { aureus }\end{array}$ & $\begin{array}{c}(+) \\
\text { B. } \\
\text { cereus }\end{array}$ & $\begin{array}{c}\text { A. } \\
\text { flavus }\end{array}$ & $\begin{array}{c}\text { A. } \\
\text { niger }\end{array}$ & $\begin{array}{c}\text { C. } \\
\text { albicans }\end{array}$ \\
\hline Ligand (HL) & 10 & 9 & 7 & 9 & 10 & 8 & 9 & 11 \\
\hline Complex (1) & 15 & 14 & 12 & $14^{-}$ & 14 & 12 & 13 & 15 \\
\hline Complex (2) & 12 & $13^{-}$ & 12 & 12 & 13 & $10^{-}$ & 12 & ${ }^{-} 14^{-}$ \\
\hline Complex (3) & $10^{-}$ & 11 & 8 & 9 & 10 & 8 & $10^{-}$ & 11 \\
\hline Complex (4) & 14 & 13 & 12 & 10 & 13 & $11^{-}$ & 12 & $14^{-}$ \\
\hline Complex (5) & $13^{-}$ & 12 & 10 & $13^{-}$ & 12 & 10 & 11 & 14 \\
\hline Amikacin & 16 & 19 & 18 & 18 & 17 & - & - & - \\
\hline Ketokonazole & -- & -- & - & - & -- & 17 & $15^{--}$ & 16 \\
\hline Fscherichia col & 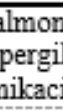 & & 1000 & & & & & \\
\hline
\end{tabular}

Table 5

EVALUATION OF ANTIMICROBIAL ACTIVITIES (DIAMETER OF ZONE OF INHIBITION IN (mm) OF THE INVESTIGATED COMPOUNDSBY AGAR DISC DIFFUSION METHOD

Bacillus cereus, Aspergillus flavus, Aspergillus niger, Candida albicans,

Standard drugs: Amikacin and Ketokonazole

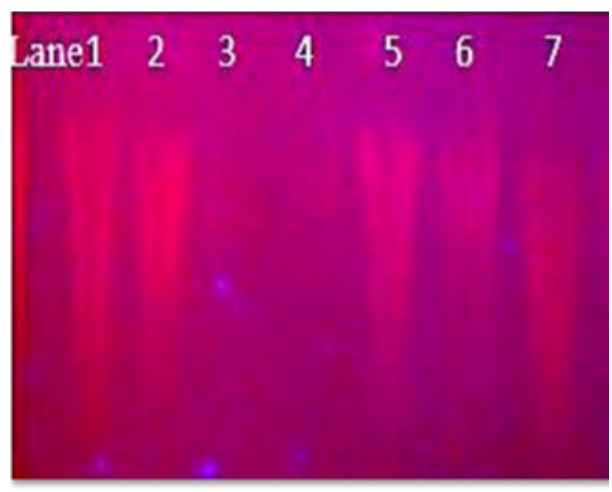

Fig. 4. Gel electrophoresis showing the chemical nuclease activity of DNA by the synthesized ligand $(\mathbf{H L})$ and complexes (1-5) in the presence of hydrogen peroxide (lane 1-7)

Lane:1 DNA alone

Lane:2 Ligand [LH] + DNA $+\mathrm{H}_{2} \mathrm{O}_{2}$

Lane:3 Complex (1) + DNA $+\mathrm{H}_{2} \mathrm{O}_{2}$

Lane:4 Complex (2) + DNA + $\mathrm{H}_{2} \mathrm{O}_{2}$

Lane:5 Complex (3) + DNA + $\mathrm{H}_{2} \mathrm{O}_{2}$

Lane:6 Complex (4) + DNA + $\mathrm{H}_{2} \mathrm{O}_{2}$

Lane:7 Complex (5) + DNA + $\mathrm{H}_{2} \mathrm{O}_{2}$

http://www.revistadechimie.ro $\quad$ REV.CHIM.(Bucharest) 69 No. 11 \2018 

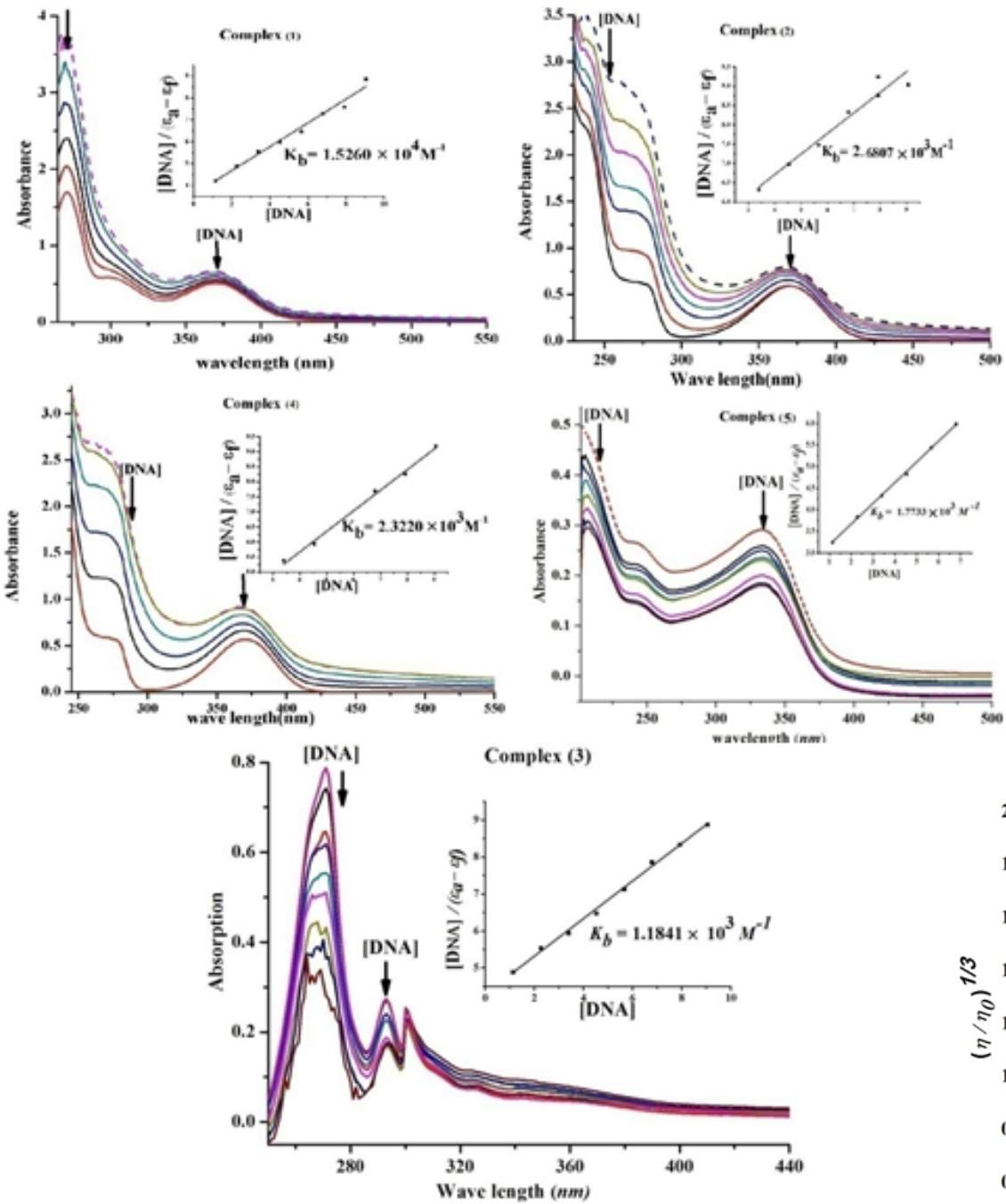

Table 6

SPECTRAL PARAMETERS FOR DNA INTERACTION WITH THE SYNTHESIZED COMPLEXES (1-5)
Fig. 5. Electronic absorption spectra of complexes (1-5) in buffer $\mathrm{pH}=7.2$ at $25^{\circ} \mathrm{C}$ in the presence of increasing amount of $\mathrm{CT}$

DNA. Arrow indicates the changes in absorbance upon increasing the CT DNA concentration. Inset: plot of [DNA] / $\left(\varepsilon_{\mathrm{a}}-\varepsilon_{\mathrm{af}}\right)$ vs [DNA] for the absorption titrations of CT DNA with complexes (1-5)

\begin{tabular}{|c|c|c|c|c|c|c|c|}
\hline Complexes & $\begin{array}{l}\lambda_{\max } \\
\text { free } \\
(\mathrm{nm})\end{array}$ & $\begin{array}{c}\lambda_{\max } \\
\text { bound } \\
\text { (nm) }\end{array}$ & $\begin{array}{c}\Delta \lambda \\
(\mathrm{nm})\end{array}$ & Types of Chromism & $\underset{\%}{\text { Chromim }}$ & $\begin{array}{l}\text { Binding } \\
\text { constant } \\
\mathrm{K}_{\mathrm{b}} \mathrm{M}^{-1}\end{array}$ & $\begin{array}{c}\Delta \mathrm{G}_{\mathrm{b}}^{-} \\
\mathrm{KJ} \cdot \mathrm{mol}^{-1}\end{array}$ \\
\hline (1) & 367 & 372 & 05 & Hypo \& Red shift & 28.47 & $1.5260 \times 10^{4}$ & -23.8707 \\
\hline$(2)$ & $366^{-}$ & 371 & $05^{-}$ & Hypo \& Red shift & 26.98 & $2.6807 \times 10^{3}$ & -19.5516 \\
\hline (3) & 292 & 294 & 02 & Hypo \& Red shift & 36.10 & $1.1841 \times 10^{5-}$ & -17.5362 \\
\hline (4) & 366 & 372 & 06 & Hypo \& Red shift & 37.60 & $2.3220 \times 10^{3}$ & -19.2050 \\
\hline (5) & $333^{-}$ & 336 & 03 & Hypo \& Red shift & 36.97 & $1.7733 \times 10^{3^{-}}$ & -18.5281 \\
\hline
\end{tabular}

to the complex. While the concentration of DNA increases from $1.1308 \times 10^{-5}$ to $9.0464 \times 10^{-5} \mathrm{M}$, hypochromic shifts of the intraligand bands were observed accompanied by a moderate bathochromic (red) shifts with range of 2-6 nm for complexes (1-5). The observed results of hypochromism effect with a red shift revealed that the interaction between complexes (1-5) and CT DNA could be non-covalent intercalative binding. The binding constant $\left(K_{b}\right)$ values are calculated from the ratio of the slope to the intercept of the plot of [DNA] / $\left(\varepsilon_{a}-\varepsilon_{f}\right) \times 10^{-8} \mathrm{Vs}$ [DNA] $\times$ $10^{-5} \mathrm{M}$ by Wolfe-Shimmer equation and $\Delta \mathrm{G}^{\#}$ values for these complexes were calculated by Van't Hoff equation which indicate that the mixed ligand complexes can interact with DNA in a spontaneous manner and also the percentage of chromicity $(\mathrm{H}, \%)$ for these complexes were determined [12]. The results are summarized in table 6. From the observed results, it is clear that complex (1) has higher binding efficacy via intercalation and other complexes may bind to DNA via groove binding.

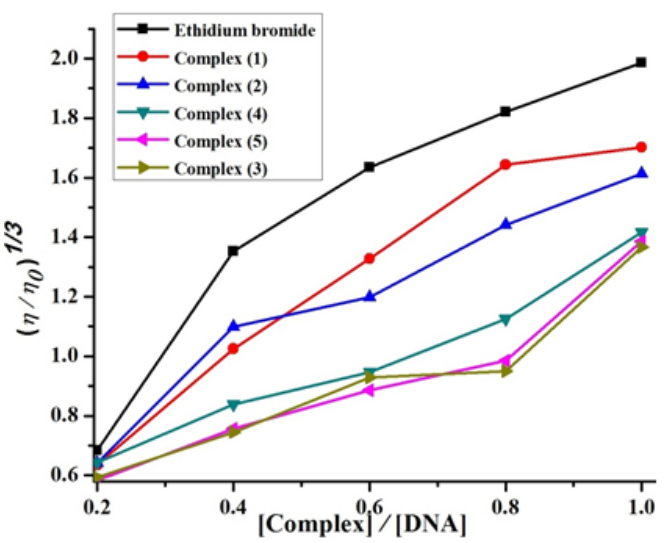

Fig. 6. Plot of relative specific viscosity $\left(\eta / \eta_{0}\right)$ versus $\mathrm{R}=[$ Complex $] /[\mathrm{DNA}]$

(c) Evaluation of DNA binding affinity by Viscosity titration measurements

The interaction between the complexes (1-5) and DNA was investigated by viscosity measurements. Ethidium bromide is used as a well known DNA classical intercalator which increases the viscosity strongly by lengthening the DNA double helix through intercalation. While increasing the concentration of complexes (1-5), the relative viscosity of complexes also increases steadily similar to the performance of ethidium bromide. The increased degree of viscosity may depend on the binding affinity to DNA and the observed values were in the following order EB > (1) $>(2)>(3)>(4)>(5)$ (fig. 6). The significant increase in viscosity of the complexes is obviously due to the partial insertion of the ligand between the DNA base pairs leading to an increase in the separation of base pairs at intercalation locations, hence an increase in overall DNA contour length [60]. 


\section{Conclusions}

The work described in this report involves the synthesis of novel water soluble mixed ligand complexes. The spectral data of the complexes (1-5) suggest an octahedral geometry of the monomeric type and [MLL'] stoichiometry. The lower electrical conductivity values reveal that they are nonelectrolytes. Cyclic voltammogram showed that complexes (1-5) were of $M(I I) / M(I)$ redox couple correspond to quasi reversible one electron transfer process. Complexes (1-5) have exposed higher potent activity than ligand $(\mathbf{H L})$ in antimicrobial and antioxidant studies. The Gel electrophoresis results revealed that complexes (1) and (2) have been revealed a significant DNA cleavage efficiency than others in the presence of hydrogen peroxide. The observed DNA binding results for the complexes (1-5) by electronic absorption and DNA binding affinity results by viscosity titration measurements were lesser than Ethidium bromide (control). DNA binding results also indicates that complex (1) is bound to DNA via intercalation and other complexes may bind to DNA via groove binding. The negative Gibbs free energy change values $\left(\Delta \mathrm{G}^{*}\right)$ indicate that the mixed ligand complexes can interact with DNA in a spontaneous manner.

Acknowledgments: The authors express their heartfelt thanks to the Department of Science and Technology (DST) -Science and Engineering Research Board (SERB-Ref.No.SR/FT/CS-117/2011dated 29.06.2012) New Delhi for financial assistance and also express deepest gratitude to the Managing Board, Principal and Chemistry Research Centre, Mohamed Sathak Engineering College, Kilakarai for providing research facilities and constant encouragements.

\section{References}

1.EBRAHIMIPOUR, S.Y., SHEIKHSHOAIE, I., CASTRO, J., DUSEK, M., TOHIDIYAN, Z., EIGNER, V., KHALEGHI, M., RSC.Adv., 5, 2015, p. 95104 2.ABU-SURRAH, A.S., KETTUNEN, M., Curr.Med.Chem., 13, 2006, p. 1337

3.ANNARAJ, B., MITU, L., NEELAKANTAN, M.A., J.Mol.Struc., 1, 2016, p. 1104

4.ANDONI, M., POP, R., SOICA, C.,SIMU, G., M.,ILICI,M., ARDELEAN,S., ONISEI, D., DEHELEAN, C.A., Rev. Chim. (Bucharest), 66, no. 5, 2015, p. 637

5. BENITEZ, J., BECCO, L., CORREIA, I., LEAL, S.M., GUISET, H., PESSOA, J.C., TANCO, S., ESCOBAR, P., MORENO, V., GARA, B., GAMBINO, T.D., J.Inorg. Biochem., 105, 2011, p. 303

6.SASMAL, P.K., PATRA, A.K., NETHAJI, M., CHAKRAVARTY, A.R., Inorg.Chem., 46, 2007, p. 11112

7.THUNG CHEW, S., MUN LO, K., KOON LEE,S., PIEW HENG, M., YEW TEOH, W., SHIN SIM, K., WAITAN, K., Eur.J.Med.Chem., 76, 2014, p. 397

8.ZHANG, S., ZHU, Y., TU, C., WEI, H., YANG, Z., LIN, L., DING, J., ZHANG, J., GUO, Z., J.Inorg.Biochem., 98, 2004, p. 2099

9. MAHESWARI, P.U., PALANIANDAVAR, M., Inorg.Chim.Acta, 357, 2004, p. 901

10.VIJAYAKUMAR, K., VIJAYA ANAND, A., MANIKANDAN, R., Int.J. Res.Stud. Bio.Sci., 3(5), 2015, p. 145

11. BLASCO, A.J., GONZALEZ, M.C., ESCARPA, A., Anal.Chim.Acta., 511,2004, p. 71

12. DHAVEETHU RAJA, J., SAKTHIKUMAR, K., J.Chem.Pharm.Res., 7(10S), 2015, p. 23

13. CHOI, C.W., KIM, S.C., HWANG, S.S., CHOI, B.K., AHN, H.J ., LEE, M.Y., PARK, S.H., KIM, S.K., Plant Sci., 163, 2002, p. 1161

14. PATEL, A., PATEL, A., PATEL, A., PATEL, N.M., Pharmacogn.Res., 2, 2010, p. 152

15.NISHIKIMI, M., APPAJI, N., YAGI, K., Biochem.Biophys. Res.Commun., 46, 1972, p. 849

16.GARATT, D.C., The Quantitative Analysis of Drugs., $3^{\text {rd }}$ Edn., Chapman and Hall Ltd, Japan, 1964
17. KOORIYADEN, F.R., SUJATHA, S., ARUNKUMAR, C., Polyhedron, 97, 2015, p. 66

18. JOSEYPHUS, R.S., NAIR, M.S., Arab.J .Chem., 3, 2010, p. 195

19. DEY, D., DE, A., PAL, S., MITRA, P., RANJANI, A., GAYATHRI, L., CHANDRALEKA, S., DHANASEKRAN, D., AKBARSHA, M.A., KOLE, N., BISWAS, B., Indian J.Chem., 54A, 2015, p. 170

20. RAMAN, N., JEYAMURUGAN, R., SAKTHIVEL, A., MITU, L., Spectrochim.Acta A., 75, 2010, p. 88

21. CHARIES, J.B., DATTAGUPTA, N., CROTHERS, D.M., Biochemistry, 21, 1982, p. 3933

22. SILVERSTEIN, M., WEBSTER, X., Spectrometric Identification of Organic Compounds, 6 $6^{\text {th }}$ Edn., Willey, New York, USA, 1998

23. SINGH, A.K., PANDEY, O.P., Spectrochim.Acta A., 85, 2012, p. 1

24. GWARAM, N.S., MOHD ALI, H., KHALEDI, H., AMEEN ABDULLA, M., HADI, A.H.A., KWAI LIN, T., CHING, C.L., LIN OOI, C., Molecules, 17, 2012, p. 5952

25. TAS, E., ASLANOGLU, M., KILIC, K., KAPLAN, O.H., J.Chem.Res., 4, 2006, p. 242

26. AAZAM, E.S, EL HUSSEINY, A.F., AL-AMRI, H.M., Arab.J .Chem., 5, 2012, p. 45

27.RAMAN, N., DHAVEETHU RAJA, J., SAKTHIVEL, A., Russ.J.Coord.Chem., 34, 2008, p. 400

28.LI, Y., YANG, Z.Y., LIAO, Z.C., HAN, Z.C., LIU, Z.C., Inorg.Chem.Commun., 13, 2010, p. 1213

29.MASOUD, M.S., AMIRA, M.F., RAMADAN, A.M., EL-ASHRY, G.M., Spectrochim. Acta A., 69, 2008, p. 230

30.GHOSH, T., PAL, S., J.Chem.Sci., 127, 2015, p. 120

31. GUPTA, L.K., BANSAL, U., CHANDRA, S., Spectrochim.Acta A., 66 , 2007, p. 972

32. YIEMER, A.M., Review of catalysts, 2, 2015, p. 14

33. SHAKIR, M., ABBASI, A., AZAM, M., KHAN, U., Spectrochim.Acta A., 79, 2011, p. 1866

34. LEVER, A.B.P., Inorganic Electronic Spectroscopy, $2^{\text {nd }}$ Edn., Elsevier, Amsterdam, Foundations of Electron Spin Resonance, Academic Press, New York, 1978

35.DAS, B.K., BORA, S.J., CHAKRABORTTY, M., KALITA, L., CHAKRABARTY, R., BARMAN, R., J.Chem.Sci., 118, 2006, p. 487

36. SINGH, D.P., KUMAR, R., MALIK, V., TYAGI, P., Trans.Met.Chem., 32, 2007, p. 1051

37. LEVER, A.B.P., Electronic spectra of $\mathrm{d}^{\mathrm{n}}$ ions in Inorganic Electronic Spectroscopy, $2^{\text {nd }}$ Edn., Elsevier, Amsterdam, Netherlands, 1984

38. KRIZA, A., DIANU, M.L., STANICA, N., DRAGHICI, C., POPOIU, M., Rev.Chim. (Bucharest), 60, no. 6, 2009, p. 557

39. GUNER, S., KARABOCEK, S., KAKLIKKAYA, I., Bioorg.Med.Chem., 7, 1999,p. 329

40.ALI KHANA, T., NASEEMA, S., SHAHPER, N., SHAKIRA, M., Spectrochim.Acta A., 73, 2009, p. 622

41. HALLI, M.B., SUMATHI, R.B., KINNI, M., Spectrochim.Acta A., 99, 2012, p. 46

42. KIVELSON, D., NEEMAN, R., J.Chem.Phys., 35, 1961, p. 149

43. SYAMAL, A., Chem.Edu., 62, 1985, p. 143

44. SHARMA, A.L., SINGH, I.O., SINGH, H.R., KADAM, R.M., BHIDE, M.K., SASTRY, M.D., Trans.Met.Chem., 26, 2001, p. 532

45. HATHAWAY, B.J., WILKINSON, G., GILLARD, R.D., MCCLEVERTY, J.A., Comprehensive Coordination Chemistry, Pergamon, Oxford press, UK, 1987

46. CHAKRAVARTY, A.R., SHYAMALA, A., Polyhedron, 12, 1993, p. 1545 47. REVATHI, N., SANGARGANESH, M., RAJESH, J., DHAVEETHU RAJA, J., J .Fluoresc., 2017, DOI:10.1007/s10895-017-2118-y, ISSN 1053-0509 48. BRAND-WILLIAMS, W., CUVELIER, M.E., BERSET, C., Lebensmittel Wissenschaftund Technologies, 28, 1995, p. 25

49. SUBRAMANIAN, R., SUBRAMANIYAN, P., RAJ, V., Springer plus., 2 , 2013 , p. 28

50.INBATHAMIZH, I., MEKALAIPONNU, T., J ANCY MARY, E., J.Pharm.Res., 6, 2013, p. 32

51. DOWDING, J.M., DOSANI, T., KUMAR, A., SEAL, S., SELF, W.T., Chem.Commun., 48, 2012, p. 4896

52. PERUMAL, P., RAJASREE, R., Eur.J.Med.Chem., 40, 2005, p. 225 
53.THIMMAIAH, K.N., LLOYD, W.D., CHANDRAPPA, G.T., Inorg.Chim.Acta, 106, 1985, p. 81

54. RAMAN, N., DHAVEETHU RAJA, J., J.Serb.Chem.Soc., 73, 2008, p. 1063

55. HUG, C.A.M.A., FOUZIA, S., Indian J.Chem., 54B, 2015, p. 551

56. RAMAN, N., DHAVEETHU RAJA, J., SAKTHIVEL, A., J.Chem.Sci., 119, 2007, p. 303
57. FENTON, H.J.H.J ., J.Chem.Soc., 65, 1894, p. 899

58. BABU, M.S.S., REDDY, K.H., PITCHIKA, G.K., Polyhedron, 26, 2007, p. 572

59.MANIKANDAMATHAVAN, V.M., PARAMESWARI, R.P., WEYHERMULLER, T., VASANTHI, H.R., NAIR, B.U., Eur.J .Med.Chem., 46, 2011, p. 4537

60. PARVEEN, S., ARJ MAND, F., Spectrochim.Acta A., 85, 2012, p. 53

Manuscript received: 4.03 .2018 